\title{
Social Portrait of a Pupil of the Simferopol Correctional Shelter for Minors (Late Xix - Early Xx Centuries)
}

\section{Retrato social de un alumno del albergue correccional para menores de Simferopol (finales del siglo XIX - principios del siglo $\mathbf{X X )}$}

Dmitriy Olegovich Egorov*

Kazan Federal University, Russia

ORCID: https://orcid.org/0000-0001-8030-9101

Alla Anatolyevna Zadereychuk Vernadsky Crimean Federal University, Russia ORCID: https://orcid.org/0000-0003-0140-1060

Valeria Andreevna Maslennikova Vernadsky Crimean Federal University, Russia ORCID: https://orcid.org/0000-0001-8807-5776

*Correspondence

Email: dmitriy.m.egorov@mail.ru
Cite as:

Egorov, D., Zadereychuk, A., \& Maslennikova, V. (2020). Social Portrait of a Pupil of the Simferopol Correctional Shelter for Minors (Late Xix - Early Xx Centuries). Propósitos y Representaciones, 8 (SPE3), e746. Doi: http://dx.doi.org/10.20511/pyr2020.v8nSPE3.746 


\section{Summary}

The article presents a multiple-criteria analysis of the composition of the Simferopol correctional shelter of the late XIX - early XX centuries. The social well-being of a child who showed elements of destructive behavior is assessed, the role of an educational institution in the life of juvenile delinquents is examined. The authors compiled a social profile of the pupil of the Simferopol correctional shelter, based on dominant indicators according to different criteria: the grounds for sending juvenile delinquents to the shelter, their age, the length of stay of juvenile offenders in the correctional institution, the family composition and literacy of the delinquent, religious and social status, place of residence, crimes committed, determining the definition of juvenile delinquents in a shelter, further life after release. The article analyzes the misconduct of foster children in a shelter and considers the system of punishment for juvenile delinquents.

Keywords: Tauride province, Simferopol correctional shelter, crime, juvenile offenders, repeat offenders, social profile.

\section{Resumen}

El artículo presenta un análisis de criterios múltiples de la composición del albergue correccional de Simferopol de finales del siglo XIX y principios del XX. Se evalúa el bienestar social de un niño que mostró elementos de comportamiento destructivo, se examina el papel de una institución educativa en la vida de los delincuentes juveniles. Los autores elaboraron un perfil social del alumno del albergue correccional de Simferopol, basado en indicadores dominantes según diferentes criterios: los motivos de envío de los delincuentes juveniles al albergue, su edad, el tiempo de permanencia de los delincuentes juveniles en el establecimiento correccional, composición familiar y alfabetización del delincuente, condición religiosa y social, lugar de residencia, delitos cometidos, determinación de la definición de delincuentes juveniles en un refugio, vida posterior a la liberación. El artículo analiza la mala conducta de los niños adoptivos en un refugio y considera el sistema de castigo para los delincuentes juveniles.

Palabras clave: provincia de Tauride, albergue correccional de Simferopol, delincuencia, delincuentes juveniles, reincidentes, perfil social.

\section{Introduction}

An active study of the identity of a juvenile delinquent poses a challenge for the scientific world - to analyze the motives of children's antisocial behavior, and identify the associated dangers in connection with the prospect of reducing the age of criminal responsibility. Turning to the past, which demonstrates the successful implementation of educational measures for juvenile delinquents, helps to introduce new elements into the penitentiary re-socialization of juvenile offenders.

Correctional institutions for minors, with the proper education organization, are considered not only to prevent crime, but also correct juvenile delinquents (Grishakov, 1923). The problems of child crime attracted increased attention in the first decade after the abolition of serfdom. The plight of the peasants contributed to the weakening of the family tradition, cohesion. These circumstances created a favorable environment for the determination of juvenile delinquency. The prisons and detention centers of the Tauride province were filled with "stumbled" children. To protect minors from the harmful effects of prison life, they were sent to correctional shelters.

The objective of this study is to compile a social profile of a student of the Simferopol correctional shelter for minor children (late XIX - early XX centuries). Identification of various features helps to consider in details the motivational complex of manifestations of destructive 
behavior on the part of minor children, which subsequently helps to level the problem of criminal behavior.

\section{Methods}

The study used a systematic method to analyze the criminal behavior of juvenile delinquents. The method of microhistory, which H. Medic summed up as a "sister of the history of life" (Medik, 1994) reconstructs the social well-being of a minor offender. The study based on a comparative method revealed a quantitative predominance of juvenile delinquents among a number of indicators, which allows us to compile a social portrait of a pupil of the Simferopol correctional shelter for minor children (late XIX - early XX centuries).

Charting is based on information from statistical codes of reports of the Main Prison Directorate (Russia. Main Prison Directorate. Report on the Main Prison Administration for 1891, 1893; Russia. Main Prison Directorate. Report on the Main Prison Administration for 1892, 1894; Russia. Main Prison Directorate. Report on the Main Prison Administration for 1894, 1896; Russia. Main Prison Directorate. Report on the Main Prison Administration for 1898, 1900; Russia. Main Prison Directorate. Report on the Main Prison Administration for 1902, 1904).

The social portrait is based on average indicators, where the dominant groups are distinguished, which form the basis of the social portrait of a minor offender.

The social profile of the pupil of the Simferopol correctional shelter is based on certain criteria. Juvenile offenders are classified by grounds for admission, previous conviction, age, and literacy. Their class, place of residence, marital status and religion are also considered. The average time spent by pupils in the shelter and their misconduct are also studied and presented.

\section{Results and Discussion}

Statistical studies of child crime indicate that the number of juvenile delinquents in the Russian Empire increased yearly. As the data presented in (Fig. 1) show, the increase in juvenile delinquents prevails over the increase in adult delinquents, which echoes the conclusions of L.M. Vasilevskii about a sharp increase in deviant behavior among children (Vasilevskii, 1923).

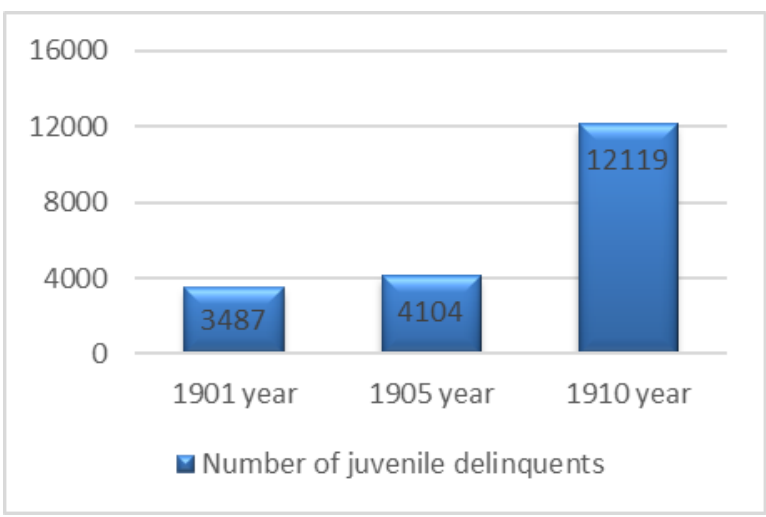




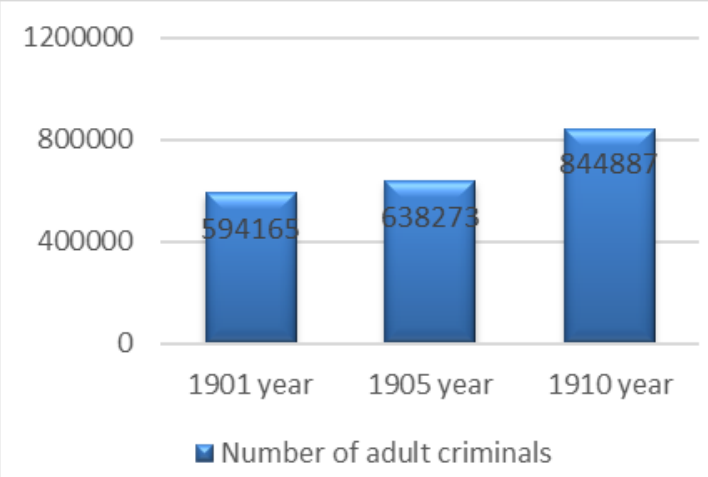

Fig. 1. Quantitative data of juvenile and adult offenders in 1901-1910.

Data compiled by the authors on the basis of reports on the Main Prison Directorate (Russia. Main Prison Directorate. Report on the Main Prison Administration for 1901, 1903; Russia. Main Prison Directorate. Report on the Main Prison Administration for 1905, 1906; Russia. Main Prison Directorate. Report on the Main Prison Administration for 1910, 1912).

In 1901-1910, the increase among juvenile delinquents was 247.5\% (Vasilevskii, 1923). The increase in the number of juvenile delinquents created an additional burden on the penitentiary system. The lack of correctional shelters for minors led to the fact that every year more than 2 thousand children were put in prisons, and released therefrom with new knowledge acquired from experienced criminals (Grishakov, 1923). The establishment of the Simferopol correctional shelter was of great importance for society. It provided an opportunity to correct the "stumbled" child. In the case of re-education, the main attention was paid to "communicating basic religious concepts", accustoming to work, developing a sense of duty and respect for other people's property. Stimulating the spiritual and moral development of the pupils, the shelter management demanded the boys be engaged in physical labor for the whole day.

In the Tauride province, the shelter admitted children under 17 years of age. In the whole country, each correctional institution independently set the age limit for its pupils. Juvenile delinquents from 10 to 17 years old, placed in educational and correctional shelters were kept until their complete correction. At the discretion of the justice of the peace, a minor who committed crime, could be given under responsibility to trustworthy people or parents, which happened in $75 \%$ of cases (Maksimov, 1913).

$36 \%$ of juvenile offenders were sent to a correctional shelter in the Tauride province, according to a court sentence. We should note that, on average, $85.3 \%$ of children in the Russian Empire were sent to correctional shelters according to a court sentence (Talberg, 1882). Also, in the Tauride province, placing children in a correctional shelter during the investigation (30\%) and by order of the administration in $23 \%$ was a common practice. In addition, children were admitted to the Simferopol correctional shelter at the request of parents or other relatives in agreement with the board of the community (Talberg, 1882). In Simferopol correctional shelter, the majority of pupils - $60 \%$ were admitted to the shelter after the first trial, and repeat offenders accounted for $32 \%$. About $20 \%$ of the boys in the first year after leaving the shelter were again put on trial.

Most of the juvenile delinquents (35\%) were sent to the Simferopol correctional shelter during the "pubertal age" of 14-16 years, which was noted by researchers as the most dangerous and critical. The next group by the number of juvenile delinquents is 16-18 year olds (28\%). Among them were mainly those showing misbehavior, or committed a criminal act at a more conscious age. The average period of education in correctional shelters of the Russian Empire ranged about 3 years (Talberg, 1882). Practically the same can be said about the Tauride prov- 
ince; most of the boys stayed 2 to 3 years $(16.5 \%)$ in the shelter, however, there were quite a lot of those who lived in the shelter up to 5 years $(8.2 \%)$. The term of serving varied from the age of admission. Due to the fact that most of the boys were admitted during the "pubertal age", more than half of the pupils were released at the age of 17-18 years. Children of 13-15 years old were released least of all since this age was recognized as critical for boys and their release could lead to repeat crime.

In the Tauride province, most of the pupils had a complete family in $35 \%$ of cases, but a more detailed discussion revealed that some did not live together. $20 \%$ of the pupils of the Simferopol shelter had a mother only, while the percentage of cases with the father asthe only parent reached $12 \%$. As can be seen from the extracts, quite often the mother married another, or began to live with a man (7\%). Often, a man was unhappy with the boy's stay in the house, showing physical abuse. The same thing happened when the widower married again, there were about $9 \%$ of such cases in the Tauride province. Orphans turned out to be left to their own devices, and such people in the Simferopol correctional shelter for juvenile delinquents accounted for $10 \%$. The number of illegitimate children was small.

The share of urban children significantly exceeded the share of rural children: $81 \%$ and $15 \%$, respectively; the place of residence of the rest was unclear. As a rule, the rural community considered it their duty to help the boy in gaining independent income (Demidov Lyceum of Law (Yaroslavl)). In the cities, they had no choice but to beggary or theft (Vasilevskii, 1924). Most of the juvenile delinquents came from petty bourgeois families $-41 \%$, followed by peasant children - $27 \%$ and soldier children - about $10 \%$. Among merchants and other honorable citizens, the level of children sent to the shelter and other correctional institutions fluctuated at the level of 3\% (Demidov Lyceum of Law (Yaroslavl)).

In the Russian Empire, with the general increase in literacy among the population, the share of illiterates among children in the Simferopol correctional shelter was 36\%. Most of the juvenile delinquents (43\%) were able to either write or read. Basically, the inmates of the correctional institution did not have certificates of graduation. The reasons for this were: laziness, mischief, or the expulsion of the boy from school at the initiative of the family, which employed him. Pupils who graduated from school accounted for $20 \%$ of all boys. Some pupils who took the path of correction could continue their studies outside the shelter after their release. $30 \%$ of the records about the released children contained unpleasant facts: "a near-idiot boy", "stupid", "miserable, weak-willed and hysterical boy", "an ill-disposed boy" (Report of the board of the Simferopol society of correctional shelters for 1901 and 1902).

Considering the denominational affiliation of the boys sent to the Simferopol correctional shelter, the Orthodox prevail (70.2\%) over other faiths. However, it is worth considering the uneven distribution of various faiths in cities and counties. Figure 2 shows that the percentage of boys of the Orthodox and Mohammedan religion in the correctional shelter was less than the percentage of the male population in the province, while at the same time we can talk about the numerical superiority of representatives of the Jewish religion in the shelter.

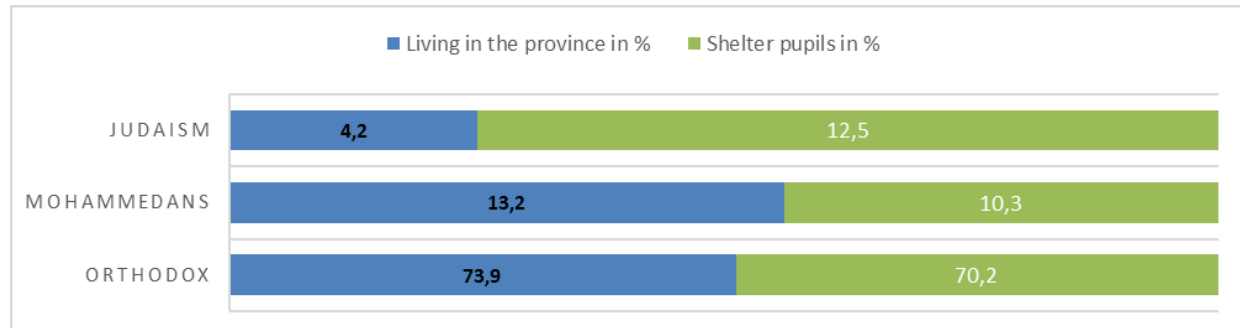

Fig. 2. Correlation of confessional composition in the Tauride province and Simferopol correctional shelter 
Data compiled by the authors on the basis of the General Census of the Russian Empire in 1897, reports on the Main Prison Directorate First General Census of the Russian Empire in 1897, 1904; Russia. Main Prison Directorate. Report on the Main Prison Administration for 1901, 1903; Russia. Main Prison Directorate. Report on the Main Prison Administration for 1905, 1906; Russia. Main Prison Directorate. Report on the Main Prison Administration for 1910, 1912).

The vast majority of juvenile offenders were sent to a shelter for theft, concealment, selling and misappropriation $-72.7 \%$. For robbery $-18 \%$, for begging and misconduct against public order - 9\%. For example, in 1891, out of 15 people who were in the shelter, all were convicted of theft, and three of them - of repeat crime (Russia. Main Prison Directorate. Report on the Main Prison Administration for 1891, 1893).

The deeds of minors in the shelter were expressed in rudeness, insolence with the teacher, cursing, a fight with friends, dissatisfaction with food. Quite often, misconduct such as pederasty or attempts thereto (Demidov Lyceum of Law (Yaroslavl)). One of the pupils, running away from the shelter, left a note "Dear mother, forgive me, but I can't live like that anymore. Boys harass me with outrages... I do not agree, so they beat me for that" (Demidov Lyceum of Law (Yaroslavl)). Most juvenile offenders committed misconduct against morality (29\%), often refused to work in workshops and showed disobedience during the educational process (19\%). Pranks and unrest, as the consequences of active games that go beyond the norms of behavior, were quite common in the Simferopol correctional shelter (19\%). Pupils were rarely caught smoking and drinking alcohol (5\% and $2 \%$ ), due to the closed type of the institution, and the lack of funds from the pupils for the purchase of tobacco and alcohol. On average, up to 400 incidents took place per year, which tended to decrease, but it is quite possible that this does not mean an improvement in the behavior of children, but that the administration of the shelter has ceased to "make dirty linen in public".

The shelter had a punishment system. In addition to reprimand, imprisonment in the punishment cell and restriction of food were provided. In 1890, these punishments were applied 60 times, 9 times per boy. In addition, the director of the shelter punished the offender by striking his hand with a ruler, which was his exclusive prerogative. Also, the pupil could be deprived of games (Russia. Main Prison Directorate. Report on the Main Prison Administration for 1891, 1893).

After being released from the shelter, most of the graduates came back to their parents' home (30\%). In services and in agriculture, $15 \%$ and $17 \%$, respectively, were employed. A considerable percentage of graduates fell into the dock the same year and again were sent to the shelter, or already to prison - $10 \%$. After their release, only a small part of the guys decided to engage in the craft, which they learned at the shelter (4\%). Most of the boys were trained in carpentry and shoemaking, as well as some of them were fond of gardening. The teachers noted difficulty for the former pupils to get settled in the profession they acquired, despite their good knowledge obtained during the training. Closed shelter life isolated them from real life (Demidov Lyceum of Law (Yaroslavl)).

The establishment of the Simferopol correctional shelter for juvenile delinquents played a role in the re-education of "stumbled" children. The shelter protected minors from close contact with more experienced criminals. However, the capacity of the shelter was very low - 50 pupils, while about 300 children a year were detained in prisons and arrest houses in the Tauride province.

The Simferopol correctional shelter, in most cases, admitted those sentenced for theft, sale and concealment. The Taurida province was characterized by re-education of children in families, as can be seen in (Fig. 3) more than $70 \%$ of children were bailed to parents, guardians 
or other trustworthy persons. The age of the children is hardly uniform, but most of children were from 13 to 15 years old. Most of them were kept, as can be seen in (Fig. 3) until the age of 17-18, and their fate was not the same as that expected by educators who taught them various disciplines and skills. The shelter had a garden, an apiary, and several workshops on its territory: carpentry and shoe, with all the necessary equipment for learning. Despite favorable conditions, only $4 \%$ of graduates earned their living by craft.

Teaching troubled children was recognized as a difficult process, which was also complicated by students' disobedience, squabble during school hours, sometimes with fights. The coarse and low-lying environment such children grow in developed a rude and familiar attitude towards older people the children respected only for physical strength.

There were a lot of illiterate children - 36\%, and this, given the general tendency to increase literacy among the population, especially in the city, where most of the children had previously lived (81\%). However, there were quite a lot of children who could write or read - $43 \%$, most of them for many reasons did not finish school.

A social portrait of a pupil of the Simferopol correctional shelter for minor children is

presented. The percentage shows which teenager was more likely to be in the shelter.

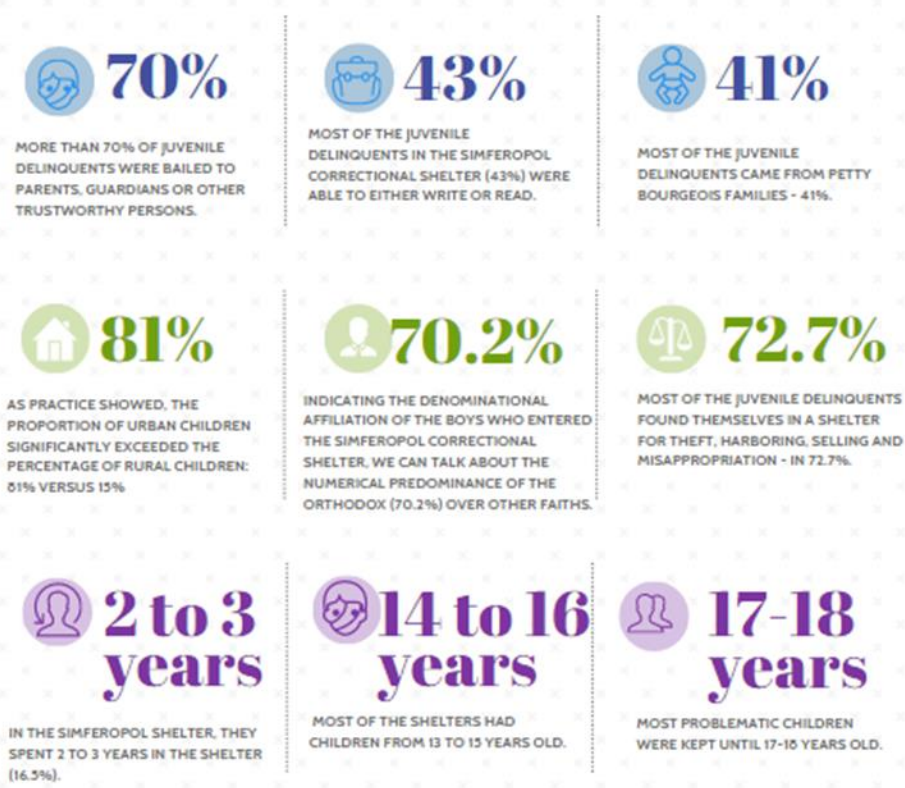

Fig. 3. Social profile of a student of the Simferopol correctional shelter for minor children (late XIX - early XX centuries).

Most of the children had two-parent families - 35\%, but this figure did not mean a happy life between father and mother.

The issue of repeat crime worried the shelter administration more than other problems. It was due to several factors. First, the worsening economic conditions of the population contributed to the depreciation of labor in the labor market, and this, in turn, "knocked down the price" of legal earnings. Secondly, the boys stayed together, both random criminals, and those who turned theft into trade, which led to the spread of criminal experience. Thirdly, the rapidly growing population in Simferopol district led to the fact that the area around the shelter quickly settled by the end of the XIX century. The director of the institution pointed out that the locals are "burst into the interests of the shelter". Communication of pupils with the local population was often unfavorable. Former pupils often came to the shelter, and juvenile criminals started out with them. 


\section{Conclusions}

The main features of the pupil of the Simferopol shelter were as follows: a teenager of 14-16 years old who was sent to the shelter after the first criminal sentence for theft, as determined by the city judge. The juvenile delinquent from an urban environment had a two-parent, mainly Orthodox, petty bourgeois family. The teenager did not run away from the shelter, but he strongly opposed the educational process, sometimes indulging in gambling and drunkenness, which provoked fights in the institution. After staying in a correctional shelter for about 3 years, the former pupil returned back to his parents. Sometimes he began to engage in agriculture or "personal service". Only about $10 \%$ of graduates of the Simferopol shelter returned to criminal life.

\section{Acknowledgements}

The work is performed according to the Russian Government Program of Competitive Growth of Kazan Federal University.

\section{References}

Demidov Lyceum of Law (Yaroslavl). Chronicle of Demidov Lyceum of Law. Book 108: Juvenile delinquents of Moscow: according to Rukavishnikovskii shelter for 1903-1907 and the Department of juvenile, City Workers House and the House of industriousness for 1908-1909 / D.N. - Yaroslavl: Publishing house of County board, 1912. - 44 p.

First General Census of the Russian Empire in 1897 / Ed. (1904). Central Statistical Committee, Ministry of Internal Affairs; Ed. N.A. Troinitskii. - XLI. Tauride province. - St. Petersburg, - $310 \mathrm{p}$.

Grishakov, N.P. (1923). Juvenile crime and the fight against it with education. - Orel: State Publishing House, $-73 \mathrm{p}$.

Maksimov, V.Ia. (1913). Business document guide. - 3rd ed., revised - Moscow: Iurist, - 1964, LXXIV $p$.

Medik, Kh. (1994). Microhistory. Thesis: Almanac, 4, - URL: https://igiti.hse.ru/data/426/313/1234/4_3_3Medick.pdf (accessed date: 16.06.2020)

Report of the board of the Simferopol society of correctional shelters for 1901 and 1902: the 19th and 20th reporting year of the Society. - Simferopol: S.B. Sinani Publishing house, 1903. -98 p.

Russia. Main Prison Directorate. Report on the Main Prison Administration for 1891. (1893). St. Petersburg: Pub. house, St. Petersburg Prison. $342+88$ p.

Russia. Main Prison Directorate. Report on the Main Prison Administration for 1892. (1894). St. Petersburg: Pub. house, St. Petersburg Prison. 166 p.

Russia. Main Prison Directorate. Report on the Main Prison Administration for 1894. (1896). St. Petersburg: Pub. house, St. Petersburg Prison. 219 p.

Russia. Main Prison Directorate. Report on the Main Prison Administration for 1898. (1900). St. Petersburg: Pub. house, St. Petersburg Prison. 196 p.

Russia. Main Prison Directorate. Report on the Main Prison Administration for 1902. (1904). St. Petersburg: Pub. house, St. Petersburg Prison. 227 p.

Russia. Main Prison Directorate. Report on the Main Prison Administration for 1901. (1903). St. Petersburg: Pub. house, St. Petersburg Prison. -. - 240 p.

Russia. Main Prison Directorate. Report on the Main Prison Administration for 1905. (1906). St. Petersburg: Pub. house, St. Petersburg Prison. 259 p.

Russia. Main Prison Directorate. Report on the Main Prison Administration for 1910. (1912). Part 2. - St. Petersburg: Pub. house, St. Petersburg Prison. 355 p. 
Talberg, D.G. (1882). Correctional shelters and colonies in Russia.- St. Petersburg: V.S. Balashev publishing house, cens. - $63 \mathrm{p}$.

Vasilevskii, L.M. (1923). Juvenile crime and juvenile court. - Tver: Oktiabr, - 190 p.

Vasilevskii, L.M. (1924). Calvary for the child. - M.: "Kniga",. - 101 p. 